\title{
Muscle strength and muscle mass in elderly women after cholecalciferol supplementation in Southern Brazil
}

\section{Força muscular e massa muscular em mulheres idosas após suplementação com colecalciferol no sul do Brasil}

\section{Fuerza muscular y masa muscular en mujeres mayores después de suplementación con colecalciferol en el sur de Brasil}

\author{
Patrícia Zambone da Silva (i) $₫$, Rodolfo Herberto Schneider (i) 1 \\ Pontifical Catholic University of Rio Grande do Sul. Porto Alegre, RS, Brazil.
}

\begin{tabular}{l} 
ARTICLE INFO \\
Article history \\
Received: 21/09/2018 \\
Accepted: 18/02/2019 \\
Published: 21/05/2019 \\
\hline Correspondent Author \\
Patrícia Zambone da Silva \\
Av. Ipiranga, 6690, prédio 84 \\
$90610-000$, Porto Alegre, RS, Brazil \\
patzambone@uol.com.br \\
(c) 2019 All rights reserved
\end{tabular}

\section{Editors}

Alfredo Cataldo Neto

Paula Engroff

\begin{abstract}
AIMS: Vitamin D is known to be vital in sustaining musculoskeletal functions, with its deficiency may cause muscle weakness and decreased bone mineral density. Vitamin D inadequacy is highly prevalent and its deficiency or insufficiency estimated to affect one billion people worldwide. It causes secondary hyperparathyroidism, bone loss, fractures and it has been associated with a number of other conditions, such as impaired muscle function (1), we decided to verify if there is an association between $25(\mathrm{OH}) \mathrm{D}$ status and handgrip strength and with lean muscle mass after cholecalciferol supplementation in elderly women.

METHODS: We studied fifty-four postmenopausal women with serum 25(OH)D below $30 \mathrm{ng} / \mathrm{mL}$ during three months. Cholecalciferol supplementation was divided into two levels according to classification: deficient (10000 units/day) and insufficient (2000 units/day). Changes in biochemical response and in body composition were assessed using dual-x-ray energy absormetry, handgrip strength and blood tests before and after supplementation. RESULTS: The majority of the sample were vitamin D deficient. There was no difference in the deficient group for handgrip strength after the supplementation $(p=0,489)$, but PTH had a statistically significant reduction $(p=0.001)$. Besides, the deficient group had a decrease in lean mass even after the intervention $(p=0.006)$. The results were similar when comparing within results of the insufficient group, however lean mass remained stable $(p=0.423)$.
\end{abstract}

CONCLUSION: Three-month cholecalciferol supplementation alone in elderly women with doses according to $25(\mathrm{OH}) \mathrm{D}$ serum was insufficient to change handgrip strength and total lean muscle mass, however secondary hyperparathyroidism was corrected.

KEYWORDS: Cholecalciferol; Muscle strength; Elderly.

\section{RESUMO}

OBJETIVOS: A vitamina D é conhecida por ser vital na manutenção das funções musculoesqueléticas, sua deficiência pode causar fraqueza muscular e diminuição da densidade mineral óssea. A inadequação da vitamina $D$ é altamente prevalente e sua deficiência ou insuficiência estimada afeta um bilhão de pessoas em todo o mundo. Causa hiperparatireoidismo secundário, perda óssea, fraturas e tem sido associada a uma série de outras condições, como função muscular prejudicada, por isso decidimos verificar se há associação entre $25(\mathrm{OH}) \mathrm{D}$ e força de preensão manual e com massa muscular magra após suplementação com colecalciferol em mulheres idosas.

MÉTODOS: Foram estudadas 55 mulheres na pós-menopausa com 25(OH)D sérica abaixo de $30 \mathrm{ng} / \mathrm{mL}$ durante três meses. A suplementação de colecalciferol foi dividida em dois níveis de acordo com a classificação: deficiente (10000 unidades/dia) e insuficiente (2000 unidades/dia). Alterações 
na resposta bioquímica e na composição corporal foram avaliadas usando a absorciometria de raios-x de dupla energia, força de preensão manual e exames de sangue antes e após a suplementação.

RESULTADOS: A maioria da amostra era deficiente em vitamina D. Não houve diferença no grupo com deficiência para força de preensão manual após a suplementação $(p=0,489)$, mas o PTH teve redução estatisticamente significativa $(p=0,001)$. Além disso, o grupo deficiente apresentou diminuição da massa magra mesmo após a intervenção $(p=0,006)$. Os resultados foram semelhantes quando comparados com resultados de grupo insuficiente, porém a massa magra permaneceu estável $(p=0,423)$.

CONCLUSÃO: A suplementação isolada de colecalciferol por três meses em mulheres idosas com doses de acordo com níveis sérico de 25(OH)D foi insuficiente para alterar a força de preensão manual e a massa muscular total, porém o hiperparatireoidismo secundário foi corrigido.

PALAVRAS-CHAVE: Colecalciferol; Força muscular; Idoso.

\section{RESUMEN}

OBJETIVOS: La vitamina D es conocida por ser vital en el mantenimiento de las funciones musculoesqueléticas, su deficiencia puede causar debilidad muscular y disminución de la densidad mineral ósea. La inadecuación de la vitamina D es altamente prevalente y su deficiencia o insuficiencia afecta a mil millones de personas en todo el mundo. Causa hiperparatiroidismo secundario, pérdida ósea, fracturas y viene siendo asociada a una serie de otras condiciones, como la función muscular perjudicada, por eso decidimos verificar si hay una asociación entre 25(OH)D y la fuerza de prensión manual y con masa muscular magra después de suplementación con colecalciferol en mujeres mayores.

MÉTODOS: Se estudiaron 55 mujeres en la post menopausia con 25(OH)D sérica debajo de $30 \mathrm{ng} / \mathrm{mL}$ durante tres meses. La suplementación de colecalciferol fue dividida en dos niveles según la clasificación: deficiente (1000 unidades/día) e insuficiente (2000 unidades/día). Alteraciones en la respuesta bioquímica y en la composición corporal fueron evaluadas usando la absorciometría de rayos-x de doble energía, fuerza de prensión manual y análisis de sangre antes y después de la suplementación.

RESULTADOS: La mayoría de la muestra era deficiente en vitamina D. No hubo diferencia en el grupo con deficiencia para la fuerza de prensión manual después de la suplementación $(p=0,489)$, pero la PTH tuvo reducción estadísticamente significativa ( $p=0,001)$. Además, el grupo deficiente presentó disminución de la masa magra aun después de la intervención $(p=0,006)$. Los resultados fueron similares cuando comparados con los resultados del grupo insuficiente, sin embargo la masa magra permaneció estable $(p=0,423)$.

CONCLUSIÓN: La suplementación aislada de colecalciferol por tres meses en mujeres mayores con dosis según los niveles sérico de 25(OH)D fue insuficiente para alterar la fuerza de prensión manual y la masa muscular total, pero el hiperparatiroidismo secundario fue corregido.

PALABRAS CLAVE: Colecalciferol; Fuerza muscular; Anciano

\section{INTRODUCTION}

Vitamin D is known to be vital in sustaining musculoskeletal functions, with vitamin D deficiency causing muscle weakness and decreased bone mineral density ${ }^{1}$. Vitamin D inadequacy is highly prevalent, with vitamin $\mathrm{D}$ deficiency or insufficiency estimated to affect one billion people worldwide ${ }^{1,2}$. Hypovitaminosis $\mathrm{D}$ is a public health problem worldwide ${ }^{3}$ and it is extremely common among elderly subjects ${ }^{1}$. It causes secondary hyperparathyroidism, bone loss, fractures and it has been associated with a number of other conditions, such as impaired muscle function ${ }^{1}$.

Low vitamin D status, reduced renal function and low dietary intake of calcium can result in mild secondary hyperparathyroidism in which may be associated with low muscle mass in elderly populations ${ }^{4}$. Changes in concentrations of both 25-hydroxyvitamin-D (25(OH)D) and parathyroid hormone (PTH) may play a role in muscle mass and strength $^{5}$. Inadequate levels of vitamin D stimulate PTH release which may have direct effects on skeletal muscle since the administration of PTH in animals can impair energy production, transfer, and utilization in skeletal muscle and also influences skeletal muscle protein and amino acid metabolism ${ }^{6,7}$.
Serum vitamin D levels have been reported to be associated with individual components of body composition. Previous studies have indicated a significant association between low serum vitamin $\mathrm{D}$ and components of abnormal body composition, manifesting as osteoporosis, sarcopenia and obesity ${ }^{8-12}$. Observational studies found serum $25(\mathrm{OH}) \mathrm{D}$ associated with different anthropometric measures and body composition measures ${ }^{13-15}$. A recent study found that an increase in serum $25(\mathrm{OH}) \mathrm{D}$ was associated with 0.23 higher lean mass percentage ${ }^{16}$. However, it is still unclear whether vitamin D status is associated with alterations in body composition, especially in the elderly.

Studies about the effect of vitamin D in skeletal muscle are still controversial. One of the problems to deal with is about what to consider the optimal range of circulating vitamin $\mathrm{D}$ levels. According to the Institute of Medicine, the optimal range $25(\mathrm{OH}) \mathrm{D}$ levels in the blood should be between $\geq 20 \mathrm{ng} / \mathrm{mL}-40 \mathrm{ng} / \mathrm{mL}$. However, The Endocrine Society recommendations are different, considering as normal blood levels between $30 \mathrm{ng} / \mathrm{mL}-50 \mathrm{ng} / \mathrm{mL}$. The decision of what to consider normal, insufficient and deficient is still an ongoing debate. Moreover, these values are established considering the bone-related outcomes 
and so cholecalciferol supplementation doses are indicated taking into consideration the needs of bone metabolism.

The impact of cholecalciferol supplementation in the muscle mass and strength in older persons is not a consensus in the literature and, besides, the availability of works with this aim is scarce. Recently, a systematic review and meta-analysis ${ }^{17}$ about vitamin $\mathrm{D}$ with or without calcium supplementation and its influence on muscle strength and mobility in community-dwelling observed no improvement in muscle strength after the administration of vitamin D. However, this study was limited on a number of research and participants.

Regarding the findings above, another systematic review and meta-analysis ${ }^{18}$ about the effects of vitamin D supplementation on muscle function showed a small positive impact on muscle strength, especially being more effective on people aged 65 years or older compared to younger.

Many other researchers ${ }^{19-22}$ have been investigating the effects of vitamin D supplementation on muscle function but results remain controversial.

Due to the explanations above, we decided to verify if there is an association between $25(\mathrm{OH}) \mathrm{D}$ status and handgrip strength and with total lean muscle mass after cholecalciferol supplementation in elderly women. Based on the previously mentioned works, the scope of this work is to compare the impact of cholecalciferol supplementation between two groups, considering deficient and insufficient elderly women.

\section{METHODS}

\section{Participants and Sample Size}

Women aged over 60 years were screened from March 2016 to December 2016. The study was conducted in South Brazil at a big city, Porto Alegre (3001'S). Fifty-four subjects who had low vitamin D levels (below $30 \mathrm{ng} / \mathrm{mL}$ ) were split into two groups (between $30 \mathrm{ng} / \mathrm{mL}-20 \mathrm{ng} / \mathrm{mL} 25(\mathrm{OH}) \mathrm{D}$ and below $20 \mathrm{ng} / \mathrm{mL}$ ). History of chronic renal failure, arthritis, Alzheimer's disease, osteoporosis, others bone diseases, diagnosis of cancer, primary hyperparathyroidism or use of calcium, bisphosphonates, cholecalciferol or corticoid were exclusion criteria. The study was approved by the local research ethics committee and all participants gave their informed consent prior to inclusion in the study (CAAE 255294113.9.0000.5336). Deficient vitamin D group had 28 subjects and insufficient vitamin D group had 26 subjects.

Sample size (n) was calculated using the statistical software SPSS version 18.0, based on the mean of handgrip strength difference and PTH among elderly women with normal levels of vitamin D compared with low levels of vitamin D in elderly women. A significance level $(p)$ of $5 \%, 80 \%$ power was considered, according to Marantes' study ${ }^{20}$. The variation means was $3.73 \mathrm{~N}$ for handgrip strength and $1.5 \mathrm{pmol} / \mathrm{L}$ for PTH. The sample size was 45 , considering losses $20 \%$, 54 participants in total.

\section{Biochemical tests}

For each participant, fasting blood samples were collected in the morning. Total calcium $(\mathrm{Ca})$, creatinine $(\mathrm{Cr})$, urea $(\mathrm{Ur})$, intact PTH $(\mathrm{PTH})$ and $25(\mathrm{OH}) \mathrm{D}$ were measured by automated standard laboratory methods. Creatinine, calcium, and urea were measured by colorimetric assay. Serum intact PTH concentrations were measured using electrochemiluminescence immunoassay; the normal range in adults is $15-68.3 \mathrm{pg} / \mathrm{mL}$. Serum $25(\mathrm{OH}) \mathrm{D}$ concentration was measured using high-performance liquid chromatography. The range of the test for serum $25(\mathrm{OH}) \mathrm{D}$ concentrations was $3 \mathrm{ng} / \mathrm{mL}$ to $120 \mathrm{ng} / \mathrm{mL}$. Vitamin D deficiency was defined as $25(\mathrm{OH}) \mathrm{D}$ concentration $<20 \mathrm{ng} / \mathrm{mL}$ and insufficiency $<30 \mathrm{ng} / \mathrm{mL}-20 \mathrm{ng} / \mathrm{mL}^{23}$. Blood tests were measured in the beginning and at the end of the study.

\section{Measure of body composition}

Body composition was assessed using Dual-energy X-ray absorptiometry (DXA) after laboratory tests in the beginning and in the end of the study. For the whole body DXA scans, we used Hologic ${ }^{\mathrm{TM}}$ General Electric. Total body weight was divided into bone mineral content, lean mass, fat mass, and fat percentage.

\section{Other covariates}

At the baseline visit, subjects were interviewed by investigators and all provided data regarding health conditions using a structured questionnaire which included age, weight, height, level of education, medications, preview diseases, personal antecedents of fractures in adulthood, tobacco use, physical exercise, and sun exposure.

\section{Intervention}

After laboratory and DXA tests, participants with $25(\mathrm{OH}) \mathrm{D}<20 \mathrm{ng} / \mathrm{mL}$ received $10000 \mathrm{U}$ per day of cholecalciferol in drops during twelve weeks plus calcium carbonate $1 \mathrm{~g} /$ day. Participants with $25(\mathrm{OH}) \mathrm{D}<30 \mathrm{ng} / \mathrm{mL}-20 \mathrm{ng} / \mathrm{mL}$ received $2000 \mathrm{U}$ per day of cholecalciferol in drops during twelve weeks plus calcium carbonate $1 \mathrm{~g} /$ day. All participants were oriented to maintain the same lifestyle as before the study. Every four weeks of treatment, they were recalled 
at the hospital to withdraw medication and bring back empty bottles. After finishing supplementation, they collected 25(OH)D, PTH, Ca and DXA.

\section{Statistical analysis}

The descriptive data were expressed by mean \pm SD or the median. Statistical comparisons between groups (before and after intervention) were performed using Student's test for patients with a normal distribution. If the data were not normally distributed, comparisons between groups were made using the Mann-Whitney test. For correlations, we used Pearson's correlation test for normal distribution and Spearman's for not normally distributed. $\mathrm{P}$ values lower than 0.05 were considered to be statistically significant.

The percentage difference was defined by the expression below:

$$
\Delta \%=100 \frac{\operatorname{var}(\mathrm{T} 1)-\operatorname{var}(\mathrm{T} 0)}{\operatorname{var}(\mathrm{T} 0)}
$$

$\mathrm{T} 1=$ after intervention

$\mathrm{TO}=$ before intervention

var $=$ variable

\section{RESULTS}

After the beginning, one died during the study due to other cause not related to the intervention and the other gave up. Thus 52 patients with age of $72 \pm 9$ years were included in the analysis. The majority of patients were non-smokers $(92,6 \%)$, non-users of sunscreen $(85 \%)$ and without regular sun exposure (95\%). The mean BMI was $28.8 \pm 6 \mathrm{~kg} / \mathrm{m}^{2}$.

The deficient group was the majority of the sample size, $54 \%$ participants.

General characteristics variables are given in Table 1. There were no significant differences between subgroups with regard to the urea, creatinine, PTH, BMI. As expected difference between groups (deficient versus insufficient) of $25(\mathrm{OH}) \mathrm{D}$ level before supplementation was significant $(13.55 \pm 3.4 \mathrm{ng} / \mathrm{mL}$ versus $25.1 \pm 3 \mathrm{ng} / \mathrm{mL} p<0.000$ )

Considering the deficient and the insufficient groups, $68 \%$ and $58 \%$ had secondary hyperparathyroidism, respectively. Handgrip strength and serum $25(\mathrm{OH}) \mathrm{D}$ were correlated before the intervention in the deficient

Table 1. General characteristics variables before the intervention.

\begin{tabular}{lccc}
\hline Variables & $\begin{array}{c}\text { Deficient } \\
(\mathbf{n = 2 8})\end{array}$ & $\begin{array}{c}\text { Insufficient } \\
(\mathbf{n = 2 4 )}\end{array}$ & $\boldsymbol{p}^{*}$ \\
\hline Age (years) & $70 \pm 7$ & $68 \pm 6$ & 0.2 \\
Serum 25(OH)D $(\mathrm{ng} / \mathrm{mL})$ & $13.55 \pm 3.4$ & $25.1 \pm 3$ & 0.000 \\
PTH $(\mathrm{pg} / \mathrm{mL})$ & $79.2 * *$ & $82.5 * *$ & 0.84 \\
Urea $(\mathrm{mg} / \mathrm{dL})$ & $43 \pm 15.5$ & $40.1 \pm 8.5$ & 0.40 \\
Creatinine $(\mathrm{mg} / \mathrm{dL})$ & $1.02 \pm 0.21$ & $0.97 \pm 0.1$ & 0.34 \\
BMI $\left(\mathrm{kg} / \mathrm{m}^{2}\right)$ & $27.6 \pm 6.3$ & $30.1 \pm 5.22$ & 0.13 \\
Total lean mass $(\mathrm{kg})$ & $37.62 \pm 5.2$ & $39.9 \pm 5.8$ & 0.15 \\
\hline
\end{tabular}

*p significance $<0.05 ; * *$ non-normal distribution

Table 2. Variables results before and after intervention for each group.

\begin{tabular}{lccc}
\hline Variables & T0 & T1 & $\boldsymbol{p}^{*}$ \\
Deficient group & Mean \pm SD & Mean \pm SD & 0.001 \\
PTH (pg/mL) & & & 0.006 \\
Lean mass (g) & $79.2(18.8-217.2)^{* *}$ & $58.24 \pm 24.25$ & 0.000 \\
25(OH)D (ng/mL) & $37630 \pm 5492$ & $36131 \pm 5486$ & 0.489 \\
Handrgrip strength (lb) & $13.60 \pm 3,5$ & $53.35(24.4-126.2)^{* *}$ & 0.018 \\
Insufficient group & $36.70 \pm 14.08$ & $37.75 \pm 11.88$ & 0.423 \\
PTH (pg/mL) & & & 0.000 \\
Lean mass (g) & $82.5(49.2-176.7)^{* *}$ & $46.45 \pm 33.54$ & 0.707 \\
25(OH)D (ng/mL) & $39874 \pm 5815$ & $35.95(27.6-47.5)^{* *}$ & $47.95 \pm 11.74$ \\
Handrgrip strength (lb) & $25.13 \pm 3.01$ & $48.42 \pm 11.92$ & \\
\hline
\end{tabular}

*p significance $<0.05 ; *$ non-normal distribution. 
Table 3. Comparison means of percentage variation between groups

\begin{tabular}{lccc}
\hline Variables & $\begin{array}{c}\text { Deficient } \\
(\Delta \%)\end{array}$ & $\begin{array}{c}\text { Insufficient } \\
(\Delta \%)\end{array}$ & $\boldsymbol{p}^{*}$ \\
\hline 25(OH)D & $328 \pm 209$ & $45 \pm 29$ & 0,000 \\
Handgrip strength** & $0 \pm 30$ & $0 \pm 15$ & 0,565 \\
PTH & $-27 \pm 23$ & $-11 \pm 24$ & 0,028 \\
Lean mass & $-3,8 \pm 6$ & $0,9 \pm 5$ & 0,006
\end{tabular}

$* p$ significance $<0.05 ; * *$ non-normal distribution.

group $(\mathrm{r}=0.35 \mathrm{p}=0.05)$. This correlation was not found in the insufficient group. There was an inverse linear correlation between hyperparathyroidism (PTH $>68 \mathrm{pg} / \mathrm{mL}$ ) and handgrip strength lower than $20 \mathrm{~kg}$ in deficient subgroup $(\mathrm{r}=-0.65 p=0.009)$. Table 2 shows the comparison between means before and after intervention for each group. During a 3-month intervention, there was no difference in the deficient group for handgrip strength after the supplementation $(p=0,489)$, but PTH had a statistically significant reduction $(p=0.001)$. Besides, the deficient group had a decrease in lean mass even after the intervention $(p=0.006)$. The results were similar when comparing within results of the insufficient group, however lean mass remained stable $(p=0.423)$. When comparing the percentage difference between groups, PTH and lean mass had lower variation in the insufficient group as showed in Table 3.

\section{DISCUSSION}

This study demonstrated that 54\% of the participants had vitamin $\mathrm{D}$ deficiency. This number stands out when compared to data from Brazilian literature that are scarce. According to the literature ${ }^{24}$, the estimates are around $41.9 \%$ of insufficiency and $15.4 \%$ of vitamin $\mathrm{D}$ deficiency. This difference can be attributed to the fact that most of the Brazilian studies on $25(\mathrm{OH})$ D levels occur in São Paulo with the geographical position 23-34'S, while Porto Alegre presents latitude $30^{\circ} 01$ 'S. The southern position of the city may favor the lower incidence of ultraviolet rays and, therefore, lower serum 25(OH)D. Participants had a handgrip strength of less than $44 \mathrm{lbs}(<20 \mathrm{~kg})$ (Table 2). According to Cruz-Jentoft et al. ${ }^{25}$ one of the determinants of sarcopenia is handgrip strength lower than $20 \mathrm{~kg}$. Therefore, this direct correlation between serum $25(\mathrm{OH}) \mathrm{D}$ levels and handgrip strength prior to intervention corroborates that hypovitaminosis $\mathrm{D}$ increases the risk of sarcopenia. In our study, the same correlation was met in the deficient group between handgrip strength and $25(\mathrm{OH}) \mathrm{D}$. Besides, a recent study $^{5}$ demonstrated that vitamin $\mathrm{D}$ deficiency was present in $41 \%$ of a sample of elderly women with sarcopenia. Another prospective, population-based study ${ }^{4}$ found that low serum $25(\mathrm{OH}) \mathrm{D}$ levels and high PTH levels increase the risk of sarcopenia in individuals over 65 years of age. In addition, these studies showed that the risk of sarcopenia was higher in subjects with baseline $25(\mathrm{OH}) \mathrm{D}$ levels below $20 \mathrm{ng} / \mathrm{mL}$ based on handgrip strength.

Although there are some studies ${ }^{19,26,27}$ associating muscle strength with vitamin $\mathrm{D}$, this issue still shows conflicting results. Marantes et al. ${ }^{20}$ found no consistent association between $25(\mathrm{OH})$ D or PTH levels with muscle mass or strength in the population aged over 50 years. In the same line, a study with older elderly did not confirm the association between serum 25(OH)D and handgrip strength ${ }^{21}$.

In this study, there was no significant variation in either lean muscle mass or handgrip strength after vitamin D supplementation. These results are in accordance with some literature that demonstrated that vitamin $\mathrm{D}$ supplementation had no significant effect on muscle mass ${ }^{20,21,28}$. However, these findings are still conflicting. Recently, a study ${ }^{29}$ demonstrated that treatment with vitamin $\mathrm{D}$ showed beneficial effects on appendicular muscle mass in pre-sarcopenic older Lebanese men and women. Although, it had no effect on muscle strength relative to placebo. Another study ${ }^{30}$ with prefrail and frail older adults and cholecalciferol supplementation in different doses during six months also demonstrated that there were no significant change in muscle strength and physical performance. In this search, it was used different doses of cholecalciferol supplementation as Lebanese study above. The different protocols of doses (2000 and $10000 \mathrm{U}$ ) does not affect results, because the doses are defined according to serum levels of $25(\mathrm{OH}) \mathrm{D}$ (insufficient $>20 \mathrm{ng} / \mathrm{mL}-29.9 \mathrm{ng} / \mathrm{mL}$ and deficient $<20 \mathrm{ng} / \mathrm{mL}$ ) based on the physiological needs already described in the literature ${ }^{2}$ to reach vitamin $\mathrm{D}$ levels of normality. 
Although vitamin D supplementation in this study was not associated with an increase in handgrip strength nor in lean muscle mass, there was a significant reduction in PTH after supplementation and a significant inverse correlation between serum $25(\mathrm{OH}) \mathrm{D}$ and PTH after the intervention. These results are in agreement with the literature ${ }^{31}$, which an inverse correlation between $25(\mathrm{OH}) \mathrm{D}$ and PTH is presented. Evidence indicates that the use of vitamin $\mathrm{D}$ or calcium in combination with vitamin D supplementation might be an effective strategy for suppressing hyperparathyroidism and minimizing the possible negative effects on muscle mass ${ }^{32}$.

With regard to the limitations of the present study, the small sample size, the study design, short duration and lack of other variables that influence muscle strength, it can only observe associations, therefore a longitudinal and prospective study with control group should be conducted to determine differences in cause and effect. It is possible that only cholecalciferol supplementation is insufficient to have a positive impact on increasing lean muscle mass. Modulation of muscle strength is a complex process. Vitamin D is one of several factors involved such as diet, hormones response, exercise. A long term study associated with other variables needs to be explored.

In conclusion, our results suggest that cholecalciferol supplementation affects PTH levels and it's associated with secondary hyperparathyroidism, especially in deficient vitamin D participants. However, even after hyperparathyroidism treatment it, was insufficient to change handgrip strength and total lean muscle mass with 12 -week treatment.

\section{ACKNOWLEGEMENTS}

Thanks to Sanofi Aventis Pharmaceutics for giving cholecalciferol supplementation and sponsorship blood tests.

\section{REFERENCES}

1. Holick MF. Vitamin D deficiency. N Engl J Med. 2007;357(3):266-81.

2. Holick MF, Binkley NC, Bischoff-Ferrari HA, Gordon CM, Hanley DA, Heaney RP, Murad MH, Weaver CM. Guidelines for preventing and treating vitamin D deficiency and insufficiency revisited. J Clin Endocrinol Metab. 2012;97(4):1153-8. https://doi.org/10.1210/ jc. 2011-2601

3. Mithal A, Wahl DA, Bonjour JP, Burckhardt P, DawsonHughes B, Eisman JA, El-Hajj Fuleihan G, Josse RG, Lips P, Morales-Torres J; IOF Committee of Scientific Advisors (CSA) Nutrition Working Group. Global vitamin D status and determinants of hypovitaminosis D. Osteoporos Int.
2009;20(11):1807-20. https://doi.org/10.1007/s00198009-0954-6

4. Visser M, Deeg DJ, Puts MT, Seidell JC, Lips P. Low serum concentrations of 25-hydroxyvitamin $\mathrm{D}$ in older persons and the risk of nursing home admission. Am J Clin Nutr. 2006;84(3):616-22; quiz 671-2. https://doi.org/10.1093/ $\mathrm{ajcn} / 84.3 .616$

5. Genaro PDS, Pinheiro MDM, Szejnfeld VL, Martini LA. Secondary hyperparathyroidism and its relationship with sarcopenia in elderly women. Arch Gerontol Geriatr. 2015;60(2):349-53. https://doi.org/10.1016/j. archger.2015.01.005

6. Baczynski R, Massry SG, Magott M, el-Belbessi S, Kohan R, Brautbar N. Effect of parathyroid hormone on energy metabolism of skeletal muscle. Kidney Int. 1985;28(5):722-7. https://doi.org/10.1038/ki.1985.190

7. Garber AJ. Effects of parathyroid hormone on skeletal muscle protein and amino acid metabolism in the rat. J Clin Invest. 1983;71(6):1806-21. https://doi. org/10.1172/jci110936

8. Han SS, Kim M, Lee SM, Lee JP, Kim S, Joo KW, Lim CS, Kim YS, Kim DK. Association between body fat and vitamin D status in Korean adults. Asia Pac J Clin Nutr. 2014;23(1):65-75.

9. Oh EG, Yoo JY, Lee JE, Hyun SS, Ko IS, Chu SH. Effects of a three-month therapeutic lifestyle modification program to improve bone health in postmenopausal Korean women in a rural community: a randomized controlled trial. Res Nurs Health. 2014;37(4):292-301. https://doi.org/10.1002/nur.21608

10. Plawecki K, Chapman-Novakofski K. Bone health nutrition issues in aging. Nutrients. 2010;2(11):1086-105. https://doi.org/10.3390/nu2111086

11. Yang YJ, Kim J. Factors in relation to bone mineral density in Korean middle-aged and older men: 20082010 Korea National Health and Nutrition Examination Survey. Ann Nutr Metab. 2014;64(1):50-9. https://doi. org/10.1159/000362425

12. Ko MJ, Yun S, Oh K, Kim K. Relation of serum 25-hydroxyvitamin D status with skeletal muscle mass by sex and age group among Korean adults. Br J Nutr. 2015;114(11):1838-44. https://doi.org/10.1017/ s0007114515003633

13. Hao Y, Ma X, Shen Y, Ni J, Luo Y, Xiao Y, Bao Y, Jia W. Associations of serum 25-hydroxyvitamin D3 levels with visceral adipose tissue in Chinese men with normal glucose tolerance. PLoS One. 2014;9(1):e86773. https:// doi.org/10.1371/journal.pone.0086773

14. Earthman CP, Beckman LM, Masodkar K, Sibley SD. The link between obesity and low circulating 25-hydroxyvitamin D concentrations: considerations and implications. Int J Obes (Lond). 2012;36(3):387-96. https://doi.org/10.1038/ijo.2011.119

15. Moschonis G, Tanagra S, Koutsikas K, Nikolaidou A, Androutsos O, Manios Y. Association between serum 25-hydroxyvitamin D levels and body composition in postmenopausal women: the postmenopausal Health 
Study. Menopause. 2009;16(4):701-7. https://doi. org/10.1097/gme.0b013e318199d5d5

16. Vitezova A, Muka T, Zillikens MC, Voortman T, Uitterlinden AG, Hofman A, Rivadeneira F, Kiefte-de Jong JC, Franco OH. Vitamin D and body composition in the elderly. Clin Nutr. 2017;36(2):585-92. https://doi. org/10.1016/j.clnu.2016.04.017

17. Rosendahl-Riise H, Spielau U, Ranhoff AH, Gudbrandsen OA, Dierkes J. Vitamin D supplementation and its influence on muscle strength and mobility in communitydwelling older persons: a systematic review and metaanalysis. J Hum Nutr Diet. 2017;30(1):3-15. https://doi. org/10.1111/jhn.12394

18. Beaudart C, Buckinx F, Rabenda V, Gillain S, Cavalier $\mathrm{E}$, Slomian J, Petermans J, Reginster JY, Bruyère $\mathrm{O}$. The effects of vitamin $\mathrm{d}$ on skeletal muscle strength, muscle mass, and muscle power: A systematic review and metaanalysis of randomized controlled trials. J Clin Endocrinol Metab. 2014;99(11):4336-45. https://doi.org/10.1210/ jc.2014-1742

19. Janssen HCJP, Emmelot-Vonk MH, Verhaar HJJ, van der Schouw YT. Vitamin D and muscle function: Is there a threshold in the relation? J Am Med Dir Assoc. 2013;14(8):627.e13-8. https://doi.org/10.1016/j. jamda.2013.05.012

20. Marantes I, Achenbach SJ, Atkinson EJ, Khosla S, Melton Iii LJ, Amin S. Is vitamin D a determinant of muscle mass and strength? J Bone Miner Res. 2011;26(12):2860-71. https://doi.org/10.1002/jbmr.510

21. Matheï C, Van Pottelbergh G, Vaes B, Adriaensen W, Gruson D, Degryse JM. No relation between vitamin D status and physical performance in the oldest old: results from the Belfrail study. Age Ageing. 2013;42(2):186-90. https://doi.org/10.1093/ageing/afs 186

22. Bischoff-Ferrari HA, Dawson-Hughes B, Orav EJ, Staehelin HB, Meyer OW, Theiler R, Dick W, Willett WC, Egli A. Monthly high-dose vitamin D treatment for the prevention of functional decline: a randomized clinical trial. JAMA Intern Med. 2016;176(2):175-83. https://doi. org/10.1001/jamainternmed.2015.7148

23. Holick MF. Vitamin D status: measurement, interpretation, and clinical application. Ann Epidemiol. $2009 ; 19(2): 73-8$.

24. Saraiva GL, Cendoroglo MS, Ramos LR, Araújo LM, Vieira JG, Kunii I, Hayashi LF, Corrêa MP, Lazaretti-Castro $\mathrm{M}$. Influence of ultraviolet radiation on the production of 25 hydroxyvitamin $\mathrm{D}$ in the elderly population in the city of São Paulo (23 degrees 34'S), Brazil. Osteoporos Int. 2005;16(12):1649-54. https://doi.org/10.1007/s00198-0051895-3

25. Cruz-Jentoft AJ, Baeyens JP, Bauer JM, Boirie Y, Cederholm T, Landi F, Martin FC, Michel JP, Rolland Y, Schneider SM, Topinková E, Vandewoude M, Zamboni M; European Working Group on Sarcopenia in Older People. Sarcopenia: European consensus on definition and diagnosis: Report of the European Working Group on Sarcopenia in Older People. Age Ageing. 2010; 39(4):412-23. https://doi.org/10.1093/ageing/afq034
26. Gumieiro DN, Murino Rafacho BP, Buzati Pereira BL, Cavallari KA, Tanni SE, Azevedo PS, Polegato BF, Mamede Zornoff LA, Dinhane DI, Innocenti Dinhane KG, Cação Pereira GJ, de Paiva SA, Minicucci MF. Vitamin D serum levels are associated with handgrip strength but not with muscle mass or length of hospital stay after hip fracture. Nutrition. 2015;31(7-8):931-4. https://doi.org/10.1016/j.nut.2014.12.022

27. Mastaglia SR, Seijo M, Muzio D, Somoza J, Nuñez M, Oliveri B. Effect of vitamin D nutritional status on muscle function and strength in healthy women aged over sixtyfive years. J Nutr Health Aging. 2011;15(5):349-54. https://doi.org/10.1007/s12603-010-0287-3

28. Redzic M, Lewis RM, Thomas DT. Relationship between 25-hydoxyvitamin D, muscle strength, and incidence of injury in healthy adults: a systematic review. Nutr Res. 2013;33(4):251-8. https://doi.org/10.1016/j. nutres.2013.02.007

29. El Hajj C, Fares S, Chardigny JM, Boirie Y, Walrand S. Vitamin D supplementation and muscle strength in pre-sarcopenic elderly Lebanese people: a randomized controlled trial. Arch Osteoporos. 2018;14(1):4. https://doi.org/10.1007/s11657-018-0553-2

30. Vaes AMM, Tieland M, Toussaint N, Nilwik R, Verdijk LB, van Loon LJC, de Groot LCPGM. Cholecalciferol or 25-hydroxycholecalciferol supplementation does not affect muscle strength and physical performance in prefrail and frail older adults. J Nutr. 2018;148(5): 712-20. https://doi.org/10.1093/jn/nxy024

31. Clark P, Vivanco-Muñoz N, Piña JT, Rivas-Ruiz R, Huitrón G, Chico-Barba G, Reza-Albarrán AA. High prevalence of hypovitaminosis D in Mexicans aged 14 years and older and its correlation with parathyroid hormone. Arch Osteoporos. 2015;10:225. https://doi.org/10.1007/s11657-015-0225-4

32. Pinheiro MM, Schuch NJ, Genaro PS, Ciconelli RM, Ferraz MB, Martini LA. Nutrient intakes related to osteoporotic fractures in men and women: the Brazilian Osteoporosis Study (BRAZOS). Nutr J. 2009;8:6. https://doi.org/10.1186/1475-2891-8-6

\section{AUTHORS:}

PATRÍCIA ZAMBONE DA SILVA

Physiatrist of São Lucas Hospital. PhD in Biomedical Gerontology at Institute of Geriatrics and Gerontology. Pontifical Catholic University of Rio Grande do Sul. Email: patzambone@uol.com.br

Orcid: https://orcid.org/0000-0002-1923-8997

RODOLFO HERBERTO SCHNEIDER

Professor in Biomedical Gerontology Graduate Program at Institute of Geriatrics and Gerontology. Pontifical Catholic University of Rio Grande do Sul.

Email: rodolfo.schneider@pucrs.br

Orcid: https://orcid.org/0000-0001-6946-8056 